\title{
ETHANOL, CORN, AND BROILER: THE INTERDEPENDENCE BETWEEN THE GLOBAL CHAINS
}

\author{
E. M. Ferragi, I. A. Nääs* \\ Graduate Program in Production Engineering, UNIP - Paulista University, São Paulo, Brazil
}

\begin{abstract}
This study aimed to assess the impact of the increase in the United States (US) ethanol production from corn, between 2000 and 2012, and extendedly in the broiler production. A comparative production analysis of the three commodities production in the US and Brazil was given in order to understand the effect on their supply chains. Results indicated that the increase in the US ethanol production was not followed by the local corn and broiler production. Reflexes of the increase in US ethanol production were found in Brazilian broiler production since the corn supply was historically dependent of the US supply. We have also found an excellent opportunity for Brazilian corn production increase with a direct result in ethanol and broiler production since further logistics, and infrastructure solutions are given.
\end{abstract}

Keywords: interrelated supply chains, energy production, feed production.

\section{ETANOL, MILHO E FRANGO: A INTERDEPENDENCIA DE SUAS CADEIAS GLOBAIS}

\section{RESUMO}

Este estudo avalia o impacto do aumento da produção do etanol nos Estados Unidos sobre a produção do milho do qual é derivado, e consequentemente sobre a produção do frango no período entre 2000 e 2012. Uma análise comparativa da produção dos três produtos nos Estados Unidos e no Brasil foi conduzida com o objetivo de contribuir para o entendimento do efeito mútuo em suas respectivas cadeias de suprimento. Resultados indicaram que o aumento da produção do etanol norte americano não foi seguido pela produção local de milho e frango. Reflexos do aumento da produção do etanol nos Estados Unidos foram observados na produção de frango no Brasil uma vez que a produção do milho apresentava dependência histórica do fornecimento norte americano. Também é destacada a oportunidade de aumento na produção de milho no Brasil com impacto direto sobre a produção de etanol de milho e frango no país, desde que medidas sejam tomadas para melhora na logística e infraestrutura interna.

Palavras- chave: inter-relação entre cadeias de suprimento, produção de energia e produção de alimentos. 


\section{INTRODUCTION}

Environmental issues and the use of finite resources have led companies, governments and researchers to seek for developing and promote the use of renewable energies. Nowadays, only $1.1 \%$ of all energy produced in the world comes from renewable sources. That leads to the risks of dependence on non-renewable sources (such as coal and oil) from $28 \%$ to $32 \%$ (WEF, 2013). The search for renewable energy sources enhances the growing international importance of ethanol as fuel and place both Brazil and the United States (USA) in a prominent position in this particular supply chain. Based on the year 2012, world ethanol production was around 78.5 billion $\mathrm{L}$, with the USA and Brazil producing nearly $90 \%$ of this total (RFA, 2013).

Researchers, academics, and practitioners indicate promising alternative sources for the production of the cellulosic ethanol; however, both sugarcane (in Brazil) and corn (in the USA) nowadays

\section{METHODOLOGY}

The focus of this study was to analyze the supply chain interaction (corn, ethanol, and broiler meat) under the global commodity chain concept (GCC) that consists of a three dimension structure, with the following aspects: (1) To enlist the chain input and output, and to describes the process of transformation of raw materials into final products. (2) To search for a geographic peculiarity related to the chains behavior. Furthermore, (3) to draw a governance structure that describes the role of each element in the chain for distributing activities and values within the chain (GEREFFI, 1994). The GCC approach provides a conceptual framework that allows examining how the production and consumption are organized across multiple national boundaries in a globalized economy. This method has been persistently and widely used in agri-food studies (JACKSON et al., 2006; TALBOT, 2009). are the inputs used in fuel production (SUN \& CHENG, 2002; FARRELL et al., 2006; SCHEMER et al., 2007). Seventy percent of maize production output is used as feed for the pig and poultry industry (EMBRAPA, 2012). The intensive use of corn as fuel in the US impacts the production of pork and chicken worldwide (FABIOSA, 2012; SANTOS et al., 2010; PIMENTEL et al.; 2008). This fact reflects the importance of an expanded view of a wider scenario of the three commodities chains and indicates the relevance of both products for the US and Brazil in the global market. The aim of this study was to analyze the US and Brazil domestic production fluctuation of each commodity (corn, ethanol, and broiler meat) between 2000 and 2012. The global commodity chain governance over the total interrelated production output was also studied and associated with the production fluctuation analysis.

It was considered that the aggregate production volume within the chains is a result of complex and ample group of approximate values. It also includes multiple decisions from individuals' producers based on variables (such as market offer and demand, international prices, and climate). The evaluation of the quantitative data from each country production was used to support macro and qualitative analysis within the concept of GCC.

Reference database was searched in government related agencies and producers association (Renewable Fuel Association RFA; Index Mundi; World Agricultural Supply and Demand Estimates Report WASDE; União da Indústria da Cana-deAçúcar - ÚNICA; Companhia Nacional de Abastecimento - CONAB; Associação Brasileira de Proteína Animal - ABPA). A chronology of the production of each commodity within the years of 2000 to 
2012 from the US and Brazil was organized. All units were consolidated in tons, and the accumulated variations were calculated for each year using the values of
2000 as reference (TABLE 1). The overall study regards the interactions between the chains (FIGURE 1).

Table 1. Ethanol, corn and broiler production and variation $(\Delta, \%)$ in the US and Brazil from 2000 to 2012

\begin{tabular}{|c|c|c|c|c|c|c|c|c|c|c|c|c|}
\hline \multicolumn{13}{|c|}{ Production $\left(10^{3}\right.$ tons $)$} \\
\hline \multirow{2}{*}{$\begin{array}{l}\text { Year } \\
\text { Crop }\end{array}$} & \multicolumn{5}{|c|}{ United States } & \multicolumn{7}{|c|}{ Brazil } \\
\hline & Ethanol & $\Delta \%$ & Corn & $\Delta \%$ & Broiler & $\Delta \%$ & Ethanol & $\Delta \%$ & Corn & $\Delta \%$ & Broiler & $\Delta \%$ \\
\hline 2000 & 4635.72 & Base & 251854.00 & Base & 13702.80 & Base & 8367.35 & Base & 42289.70 & Base & 5980.00 & Base \\
\hline 2001 & 5033.88 & 8.59 & 241337.00 & -4.18 & 14033.26 & 2.41 & 9113.64 & 8.92 & 35266.80 & 16.61 & 6740.00 & 12.71 \\
\hline 2002 & 6057.72 & 30.67 & 227767.00 & -9.56 & 14467.46 & 5.58 & 9972.35 & 19.18 & 47410.90 & 12.11 & 7520.00 & 25.75 \\
\hline 2003 & 7963.20 & 71.78 & 256229.00 & 1.74 & 14696.00 & 7.25 & 11641.81 & 39.13 & 42128.50 & -0.38 & 7840.00 & 31.10 \\
\hline 2004 & 9669.60 & 108.59 & 299876.00 & 19.07 & 15285.80 & 11.55 & 12156.97 & 45.29 & 35006.70 & 17.22 & 8490.00 & 41.97 \\
\hline 2005 & 11102.98 & 139.51 & 282263.00 & 12.07 & 15869.84 & 15.81 & 12498.40 & 49.37 & 42514.90 & 0.53 & 8950.00 & 49.67 \\
\hline 2006 & 13807.62 & 197.85 & 267503.00 & 6.21 & 15930.31 & 16.26 & 14096.81 & 68.47 & 51369.90 & 21.47 & 9340.00 & 56.19 \\
\hline 2007 & 18486.00 & 298.77 & 331177.00 & 31.50 & 16226.25 & 18.42 & 17796.19 & 112.69 & 58652.30 & 38.69 & 10310.00 & 72.41 \\
\hline 2008 & 25596.00 & 452.15 & 307142.00 & 21.95 & 16561.61 & 20.86 & 21745.51 & 159.89 & 51003.80 & 20.61 & 10940.00 & 82.94 \\
\hline 2009 & 30146.40 & 550.31 & 332549.00 & 32.04 & 15935.35 & 16.29 & 20295.83 & 142.56 & 56018.10 & 32.46 & 10980.00 & 83.61 \\
\hline 2010 & 37626.12 & 711.66 & 316165.00 & 25.54 & 16563.23 & 20.87 & 21627.43 & 158.47 & 57406.90 & 35.75 & 12230.00 & 104.52 \\
\hline 2011 & 39531.60 & 752.76 & 313949.00 & 24.66 & 16694.48 & 21.83 & 17918.39 & 114.15 & 72979.80 & 72.57 & 13050.00 & 118.23 \\
\hline 2012 & 37825.20 & 715.95 & 273819.52 & 8.72 & 16621.08 & 21.30 & 18348.79 & 119.29 & 81007.20 & 91.55 & 12650.00 & 111.54 \\
\hline $\begin{array}{l}\text { World' } \\
\text { Producer } \\
\text { Rank }\end{array}$ & $1^{\text {st }}$ & & $\mathbf{1}^{\mathrm{st}}$ & & $1^{\text {st }}$ & & $2^{\text {nd }}$ & & $3^{\text {rd }}$ & & $3^{\text {rd }}$ & \\
\hline
\end{tabular}

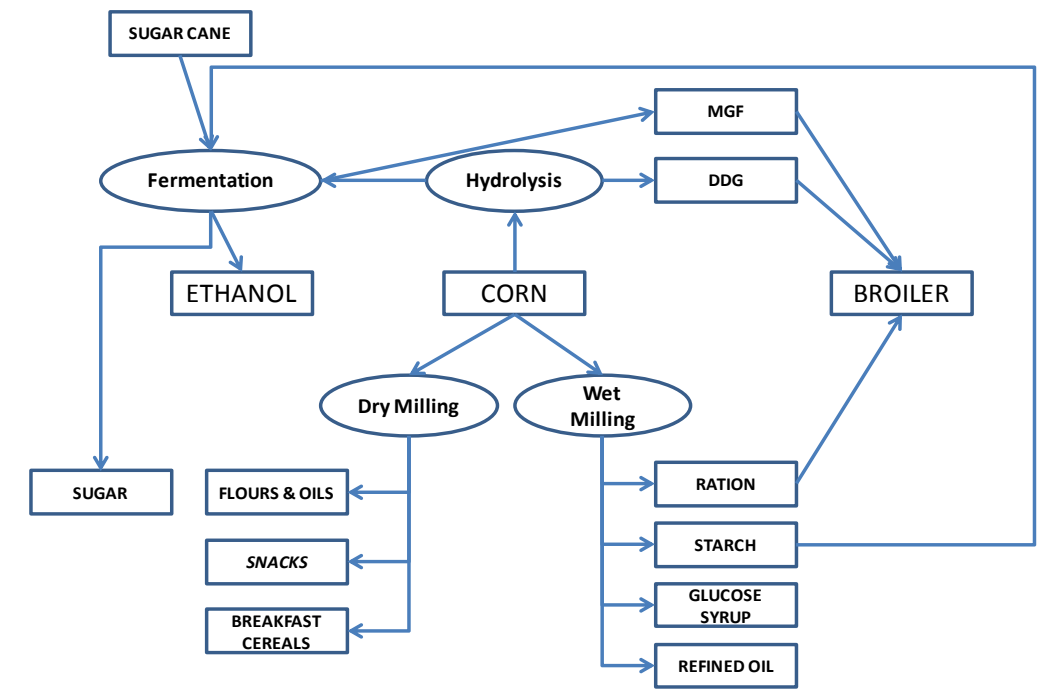

FIGURE 1. Interrelation between world ethanol, corn and broiler chains

\section{RESULTS AND DISCUSSION}

\section{Ethanol}

There are two methods for producing fuel ethanol from corn grain. The wet milling process was developed primarily to produce starch and sugar (maize sugar) for human consumption. Sugar production continues but mostly all wet milling plants also produce fuel ethanol. In this process, maize oil and corn gluten meal are also 
produced. The resulting byproduct is maize gluten feed (MGF) which contains the fiber from the maize kernel plus the steep liquor, the fermented liquid used in the initial steeping and washing processes. In the dry milling process, the corn grain is milled, and the starch is hydrolyzed with enzymes and fermented with yeast to produce ethanol. The byproduct is distiller's grains (DG) that can be marketed as a wet byproduct (WDGs) or dried to produce dry distillers' grains with soluble (DDGs). In both wet and dry milling, the starch is converted into ethanol. The remaining byproducts are high in fiber, protein and, in the case of DDGs, lipid. The maize byproducts are usually priced lower than maize grain and, therefore, could be economic sources of energy for cattle, in addition to being good protein, sources (KLOPFENSTEIN et al, 2013).

The US corn ethanol production to be added to gasoline is being expanded with governmental subsidies in taxes reduction (FIGUEIRA \& BURNQUIST, 2006). According to Banerjee (2011) there are nowadays nearly 200 distinct subsidies to produce ethanol, and it involves 209 ethanol distilleries located in 29 states. By December 2011, there were other 140 units under construction or expansion of their ethanol production capacity, and improvement of both the energy efficiency and the quality of the livestock feed. The Renewable Fuels Association (RFA) have been played a significant role in providing research data and industry analysis within the USA (RFA, 2012). In Brazil, ethanol production is derived from sugarcane, and the companies that produce fuel also produce sugar. The ratio of output varies according to the fluctuations and trends in the market. Results are sugar; anhydrous

\section{Corn}

Corn (or maize) is the most-produced grain worldwide. With global production of near 860 million tons in 2012, the largest producers were the US (32.1\%) and China $(24.4 \%)$. Brazil ranks in third place with a share of $8.3 \%$ in worlds' grain produced (FAO, 2013). Corn provides ethanol (anhydrous ethyl alcohol fuel EACA) and water. The ethanol is used in blends with gasoline, and hydrous ethanol (hydrous ethanol fuel - AEHC), or used directly as fuel in vehicles running on ethanol and flex engines. In the 2012/2013 harvest of 293 million tons of sugar cane were used for the production of sugar and 296.0 million were used for the production of ethanol (CONAB, 2013).

According to the Brazilian Department of Agriculture (MAPA, 2012), sugarcane-based ethanol production in Brazil is processed by a structure of 401 plants operating in 23 states. The União da Indústria da Cana-de-Açúcar - UNICA is a result of the merger between multiple sugar cane industry associations in the state of São Paulo. The entity represents the interests of ethanol producers face a number of successive government bodies, which, since 1975 with the implementation of the Brazilian Ethanol Program aimed to regulate the industry. The Brazilian Oil, Gas, and Biofuel Agency - ANP), in association with the Department of Agriculture (MAPA), the Ministry of Mines and Energy (MME), the Ministry of Development, Industry and Commerce (MDIC), and the Ministry of Treasury (MF), represent are currently concentrating efforts to regulate and establish the industry policies (BRASIL, 2012). From the year 2000 there have been mergers and acquisitions marked by the growing introduction of foreign capital. The sugarcane and ethanol agribusiness struggle to thrive under a scenario where in one hand the four largest industrial groups dominate around $32 \%$ of the market, and on the other, the four largest distributors concentrate around $57 \%$ of the ethanol market (MARQUES et al., 2012).

about $21 \%$ of human nutrition worldwide, and also the main energy ingredient in livestock feed. Maize is also processed into a broad range of food and industrial products including ethanol fuel. Other uses are ingredient in cosmetics, ink, glue, laundry starch, medicines, and fabrics. For 
analyzing the interdependence of the global commodities in the present study, there were used about 120 millions of tons of corn for ethanol production, and 30 million tons for broiler meat production in 2011 (NCC, 2011). With the growth of the ethanol industry and the anticipated expansion of this particular industry, the demand for maize has increased substantially. As late as $2000,60 \%$ of corn grain produced was fed to livestock and poultry. The development of the fuel ethanol industry has changed both the price of corn grain and the usage by livestock and poultry. In 2010 , only $42.9 \%$ of US maize grain was fed to livestock and poultry while $41.8 \%$ was used for fuel ethanol production and $11.2 \%$ for food (KLOPFENSTEIN, 2013).

Although criticized by the impact fuel production infers in food production (PIMENTEL et al., 2008; TIMILSINA et al, 2011; TIMILSINA et al, 2012; BANERJEE, 2011), one-third of every bushel of grain processed into ethanol is enhanced and returned to the animal feed market in the form of distiller's grains, corn gluten feed or corn gluten meal. From the 118 million of tons used for ethanol production in 2012, there were also an amount of 34.4 million tonnes of highquality livestock feed, which includes 31.6 million tonnes of distillers' grains and 2.8 million tons of corn gluten feed and meal. This fact indicates the grain destination between the fuel and food chains. The RFA also states that the ethanol production does not reduce the amount of food available for human consumption, once the ethanol is produced from field corn fed to livestock, not sweet corn fed to humans. Importantly, ethanol production utilizes only the starch portion of the corn kernel,

\section{Broiler Meat}

According to the Food and Agriculture Organization of the United Nations - FAO, of the 104 million tons of poultry meat, broiler meat reaches 82 million tons (FAO, 2013). The USA is the world' largest producer (16.5 million tons). China is the second (13.7 million tons), which is abundant and of little value (RFA, 2014). Corn chain is one of the most significant economic sectors of Brazilian agribusiness. Maize represents $37 \%$ of the national production of grains when considering only the primary productions. At the same time, it is basic to poultry and pig production input, two competitive export segments. In 2012, 55 million tons of corn, i.e., $67.9 \%$ of the total harvest in the country was used in feedstuff for the broilers produced (VALOR, 2012).

Nearly the total of ethanol produced in Brazil comes from sugarcane. There is the feasibility of producing fuel from corn due to the idle capacity of plants in between sugarcane harvesting seasons. The potential production growth for unused corn due to the lack of demand and serious logistical issues to transport and export the production. Considering the areas used to plant soybean, cotton, and corn during summertime equivalent area could be planted with corn during the short harvesting period (currently, only a portion of this field is used). It represents an additional 73 million tons of corn could be produced. This option would raise the Brazilian production to 152 million annual tons. That is without factoring in productivity increases (SILVA et al., 2014). The governance scenario where production takes place is marked by the influence of the large global corporations. These companies operate in genetic research, seed production, and the sale of grains and the control the seed market (WILKINSON, 2009). On the other hand, there is a set of business parties, which traded, processed, distributed, and sold grains that are dominant global traders in the modern agri-food system (OXFAM, 2012).

and Brazil is the third largest producer (12.6 million tons) and the first exporter (3.9 million tons) (ABPA, 2013). In Brazil, the most consumed meat is broiler meat, followed by beef and pork.

As in others sectors, a vertical integration also affects the poultry 
production in the Brazil and the USA Operating as integrators, the poultry processors supply the chicks and feed, among others, support services to the grower operators. The integrator provides the chicks and feedstuff, among other aspects of production, to the grower. These big integrators firms have invested large amounts of research and development that has created much time and money into research that has created a very efficient production process (MUHAMMAD et al., 2007). From a global market view, the presence of Brazilian companies is stronger. The country is ranked as the largest global exporter thanks to an impressive market penetration in the Middle East and Europe. Although with operations that are more geared towards the domestic market, the Asian market presence must also be highlighted (WATT, 2014). With the results from the analyzed data it was possible to visualize the following aspects: (a) the increase of ethanol production in the USA and its relationships with the local corn and broiler, as well as the Brazilian ethanol, corn and broiler production; and (b) the trends in the internalization and unification of leadership of the global chains in the three studied commodities.

Production growth of the USA ethanol was achieved at a rate of $716 \%$ over the past 12 years, with an annual average of $337 \%$. This increase indicates an unusual example of productivity that deserves attention. The USA has been able to multiply its production of ethanol from corn as a result of a clear and consistent policy of incentive to renewable fuels over the last twelve years. Although the literature identifies as a case of successful energy policy the issue of ethanol from sugarcane in Brazil (ROSILLO-CALLE \& WALTER, 2006; SORDA et al., 2010; MEYER et al., 2013) with a production increase of $119 \%$ in the same period, experts and professionals identify the lack of long term planning governmental programs. There is also an absence of explicit rules that discourage investment in the expansion of biofuel production in the country (FARINA et al., 2013). During the studied period (12 years) there was a reversal of roles maintaining the relation of approximately $50 \%$ between the world's two largest producers of ethanol. In 2000, the USA produced the corresponding amount of $55 \%$ of Brazilian production, and in 2012 Brazil produced the equivalent of $49 \%$ of USA production (FIGURE 2).

The increase in ethanol production in the USA reached expressive marks in the period studied. The same did not occur with the production of corn and chicken that had insignificant increases of $8.7 \%$ and $21.3 \%$ in the country. From the data collected, the small performance of evolution in the production of corn and chicken in the USA indicated a growth opportunity of the same commodities in Brazil of approximately $91.5 \%$ and $111.5 \%$, respectively (FIGURE 3).

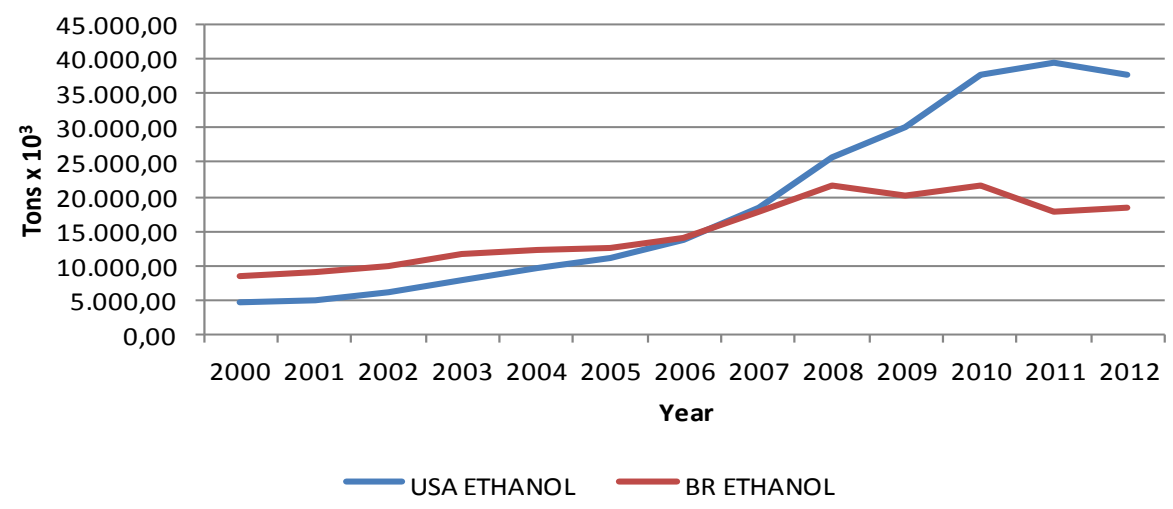

FIGURE 2. American ethanol and Brazilian ethanol production from 2000 to 2012 
The case of corn needs to be enhanced because of the growth rate of production in Brazil (91.5\%) over the USA $(8.7 \%)$ during the analyzed period. Using the current level of productivity, experts estimate that if corn is planted in areas with soybeans, cotton, and corn during the Brazilian summer, an additional amount of 73 million tons of corn could be produced. This initiative would increase total Brazilian corn production to 152 million tons (SILVA et al., 2014). Once explored, the sustainability of the Brazilian corn production could induce significant positive impacts on the poultry meat and even in the ethanol supply chains, considering that pioneering initiatives start using corn for ethanol production.
Results indicated the potential increase in maize production in Brazil, not achieved due to lack of infrastructure and logistics for transportation from the producing area to the consumption market or export. According to EMBRAPA (2012), amongst the barriers to achieving this production there is the depressed market price of corn (half the value of soybeans) and the inadequate transportation infrastructure in Brazil. Taking into account only the domestic market, a bushel of corn $(60 \mathrm{~kg})$ is $\mathrm{R} \$ 14.00$ in the Midwest of Brazil (Mato Grosso state, where corn is produced), and it double the price when it reaches the Southern region of the country, where broilers are mainly produced.



FIGURE 3. Corn and broiler production fluctuation in the US and Brazil

The governance structure of GCCs are notable by the internationalization of a small number of big companies that through direct investments start operating in several countries around the world. The verticalization process through the expansion of their operations to all the levels of the chain, acting as landowners, cattle, poultry, biofuel and grain producers; food processors; warehousing and transportation providers; as well as financial-service providers to growers. Furthermore, they provide on one hand, fertilizers and pesticides, and, on the other hand, they mediate the purchases and sales of harvests through a complicated and financed global business (OXFAM, 2012). This context agglomerate at least ten corporate groups that concentrate enormous power and influence over the GCCs' governance. Such issue highlights the importance of discussing this subject and taking actions related to the total of commodities produced in each country. Such should be the result of natural external factors, government policies, or even corporate actions resultant of economic interests under the logic of the business management of large international groups. 


\section{CONCLUSIONS}

In the period 2000-2012 the ethanol production in the US raised when compared to the evolution of fuel production in Brazil. This increase denotes the option for US domestic production of the biofuel as energy, and this fact enhanced a greater participation of Brazil in the food chain through the growth of corn and chicken production.

\section{REFERENCES}

ASSOCIAÇÃO BRASILEIRA DE PROTEÍNA ANIMAL - ABPA. Relatório Anual. Technical report. 2013.

BANERJEE, A. Food, Feed, Fuel: Transforming the competition for grains. Development and Change, v. 42, p. 529557, 2011.

BRASIL - Tribunal de Contas da União. Mercado interno de etanol. Tribunal de Contas da União. Relator Ministro Raimundo Carreiro - Brasília: TCU. 2012.

COMPANHIA NACIONAL DE ABASTECIMENTO - CONAB. Acompanhamento de safra brasileira : cana-de-açúcar, quarto levantamento, abril/2013 - Brasília. Technical report. 2013.

EMPRESA BRASILEIRA DE PESQUISA AGROPECUÁRIA - EMBRAPA. Embrapa Milho e Sorgo. Sistema de Produção 1. $8^{a}$ edição. Versão Eletrônica. 2012.

http://sistemasdeproducao.cnptia.embrapa. br/FontesHTML/Milho/CultivodoMilho_8 ed/economia.htm 2012.

FABIOSA, J.F. The long-run impacts of ethanol subsidies and ethanol expansion on the US corn and pig sectors. EuroChoices (). The Agricultural Economics Society and the European Association of Agricultural Economists, v. 11, p. 29-35, 2012.

FARINA, E.; RODRIGUES, L.; SOUZA, E.L. A política de petróleo e a indústria de
Regarding the governance model of the chains, ruled by a small group of companies operating globally, the production of each commodity appears to function under the logic of corporate decisions influenced by the commodity market.

etanol no Brasil. Interesse Nacional. Julho/Setembro, p.64-75, 2013.

FARRELL, A.E.; PLEVIN, R.J.; TUMER, B.T.; JONES, A.D.; O'HARE, M.; KAMMEN, D.M. Ethanol can contribute to energy and environmental goals. Science, v. 311, p. 506-508. 2006.

FIGUEIRA, S.R.; BURNQUIST, H.L. Programas para álcool combustível nos Estados Unidos e possibilidades de Exportação do Brasil. Agric. São Paulo, v. 53, p. 5-18, 2006.

FOOD AND AGRICULTURE ORGANIZATION OF THE UNITED NATIONS - FAO. Food Outlook, Biannual Report on Global Food Markets. Technical report. June 2013.

GEREFFI, G. The Organization of BuyerDriven Global Commodity Chains: How U.S. Retailers Shape Overseas Production Networks. In Commodity Chains and Global Capitalism, edited by G. Gereffi and M. Korzeniewics. Westport: Praeger. Pp 95-123. 1994.

JACKSON, P.; WARD, N.; RUSSELL, P. Mobilising the commodity chain concept in the politics of food and farming. Journal of Rural Studies, v. 22, p.129 141, 2006.

KLOPFENSTEIN,T.J.; ERICKSONA, G.E.; BERGERB, L.L.Maize is a critically important source of food, feed, energy and 
forage in the USA. Field Crops Research, v. 153, 5-11, 2013.

MARQUES, D.S.P.; PAULILLO, L.F.O.; VIAN, C.E.F. Ethanol tranding groups and network governance. Gestão \& Produção, v. 19, n. 4, pp. 825-840, 2012.

MEYER, P.M.; RODRIGUES, P.H.M.; MILLEN, D.D. Impact of biofuel production in Brazil on the economy, agriculture, and the environment. Animal Frontiers - The review magazine of animal agriculture, v. 3, p28-37, 2013.

MINISTÉRIO DA AGRICULTURA PECUÁRIA E ABASTECIMENTO MAPA. Relação das unidades produtoras cadastradas no Departamento da Cana-deaçúcar e Agroenergia. Sistema de Acompanhamento da Produção Canavieira. Departamento de Cana-deaçúcar e agroenergia. 2012. http://www.agricultura.gov.br/arq_editor/fi le/Desenvolvimento_Sustentavel/Agroener gia/Orientacoes_Tecnicas/Usinas $\% 20 \mathrm{e} \% 2$ 0Destilarias\%20Cadastradas/DADOS_PR ODUTORES_22-10-2012.pdf .

MUHAMMAD, A.; WHITTINGTON, A.; ANDERSON, J.; HERNDON, C. The impact of feed cost in U.S. poultry production: Implications for the impact of increased ethanol production. In: BioFuels, Food and Feed Tradeoffs Conference. 2007.

\section{NATIONAL CHICKEN COUNCIL - NCC. Broiler Chicken Industry Key Facts. 2011. http://www.nationalchickencouncil.org/abo ut-the-industry/statistics/broiler-chicken- industry-key-facts/}

OXFAM INTERNATIONAL. Cereal Secrets - The world's largest grain traders and global agriculture. Oxfam Research Reports. August 2012.

PIMENTEL, D.; MARKLEIN, A.; TOTH, M.A.; KARPOFF, M.; PAIL, G.S.; MCCOMACK, R.; KYRIAZIS, J.; KRUEGER, T. Review - Biofuel impacts on world food supply: Use of fossil fuel, land and water resources. Energies, v. 1, p.41-78, 2008.

RENEWABLE FUELS ASSOCIATION RFA . Acelerating Industry Innovation 2012. Ethanol Industry Outlook. 2012.

Ethanol Facts: Agriculture - Feeding the World, Fueling a Nation. 2014. http://www.ethanolrfa.org/pages/ethanol-

facts-agriculture.

Historic U.S. fuel Ethanol Production. 2013.

http://ethanolrfa.org/pages/statistics\#A.

ROSILLO-CALLE, F.; WALTER, A.Global market for bioethanol: historical trends and future prospects. Energy for Sustainable Development.v.10, n.1, pp 20-32. 2006.

SANTOS, R.B.N.; AMORIM, A.L.; CORONEL, D.A.; SANTOS, F.T.P. Relações de co-integração entre preço dos biocombustíveis e alimentos: Comparativo entre o etanol americano e a produção de milho no Brasil. $\mathbf{4 8}^{\circ}$ Congresso SOBER Sociedade Brasileira de Economia, Administração e Sociologia Rural. 2010.

SCHEMER, M.R.; VOGEL, K.P.; MITCHELL, R.B.; PERRIN, R.K. Net energy of cellulosic ethanol from switchgrass. Proceedings of the National Academy of Sciences of the United States of America, v. 105, p. 464-469. 2007.

SILVA, T.; VERGES, P.; ORLOVICIN, N.; POMENTA, R.Etanol de Milho no Brasil - Viabilidade de Produção. Commodity Insight. INTL FCStone. Technical Report. 2014.

SORDA, G.; BANSE, M.; KEMFERT, C. An overview of biofuel policies across the world. Energy Policy, v. 38, p.6977 6988, 2010.

SUN, Y.; CHENG, J. Hydrolysis of lignocellulosic materials for ethanol 
production: a review. Bioresource

Technology, v. 8, p.1-11, 2002.

TALBOT, J.M. The comparative advantages of tropical commodity chain analysis. In Jennifer Bair. (ed.) Frontiers of commodity chain research. Stanford University Press. California. 2009.

TIMILSINA， G.R.; BEGHIN， J.C.; MENSBRUGGHE, D.; MEVEL, S. The impacts of biofuels targets on land-use change and food supply: A global CGE assessment. Agricultural Economics, v. 43, p.315-332, 2012.

TIMILSINA, G.R.; MEVEL, S.; SHRESTHA, A. Oil price, biofuels and food supply. Energy Policy, v. 39, p. 8098 $-8105,2011$.

VALOR ECONÔMICO. Demanda para a produção de rações deve pressionar cotação do milho. 2012. http://www.valor.com.br/agro/2532744/de manda-para-producao-de-racoes-devepressionar-cotacao-domilho\#ixzz3GWRLHeMR.

WATT GLOBAL MEDIA - Poultry International Magazine. The world's leading broiler producers. 2014. http://www.wattagnet.com/Worldtoppoultr y/world_broiler_producers.html

WILKINSON, J. 2009. Globalization of Agribusiness and Developing World Food Systems. Monthlyreview.org. 2009. http://monthlyreview.org/2009/09/01/globa lization-of-agribusiness-anddevelopingworld-food-systems

WORLD ECONOMIC FORUM - WEF. Energy transitions: Past and Future. Energy Vision 2013. Technical Report. 2013. 